\title{
Linear Low Density Polyethylene/Poly (Vinyl Alcohol)/Kenaf Composites: Effect of Natural Weathering on Functional Group, Weight Loss Characteristics, Tensile, Morphological and Thermal Properties
}

(Komposit Polietilena Berketumpatan Rendah Linear/Poli (Vinil Alkohol)/Kenaf: Kesan Pencuacaan Semula Jadi ke atas Kumpulan Fungsian, Pencirian Pengurangan Berat, Sifat Tegangan, Morfologi dan Termal)

\author{
PANG AI LING, HANAFI ISMAIL* \& AZHAR ABU BAKAR
}

\section{ABSTRACT}

The development of natural fiber polymer composites is increasing worldwide and in some applications, these composites are used at outdoor rendering them exposed to ultra-violet (UV) radiation. The paper investigates the degradation behavior of linear low density polyethylene/poly (vinyl alcohol)/kenaf (LLDPE/PVOH/KNF) composites after exposure to different natural weathering durations. The composites with KNF loadings of 10, 20 and 40 parts per hundred resin (phr) were exposed to natural weathering for 3 months and 6 months, respectively. The weathered composites were characterized by Fourier transform infrared (FTIR) spectroscopy, universal testing machine, field emission scanning electron microscopy (FESEM) and differential scanning calorimetry (DSC). The FTIR analysis showed an obvious carbonyl peak in composites after weathering as an evidence of oxidation. The weight loss percentage of composites increased with respect to exposure duration due to higher absorption of UV irradiation. The tensile properties of weathered composites were lower than that of control composites and these properties also decreased with increasing exposure duration. FESEM micrographs illustrated that composites with longer exposure duration suffered more surface damaged. The crystallinity percentage was found to increase with increasing exposure duration.

Keywords: Crystallinity; degradation; kenaf (KNF); linear low density polyethylene/poly (vinyl alcohol) (LLDPE/PVOH); natural weathering

\section{ABSTRAK}

Perkembangan komposit polimer gentian semula jadi semakin bertambah di seluruh dunia dan di dalam penggunaannya, komposit ini banyak digunakan di persekitaran luaran yang terdedah kepada radiasi lampau ungu (UV). Kertas ini melaporkan kelakuan degradasi komposit polietilena berketumpatan rendah linear/poli (vinil alkohol)/kenaf (LLDPE/ $P V O H / K N F)$ selepas terdedah kepada tempoh pencuacaan semula jadi yang berbeza. Komposit dengan pembebanan KNF 10, 20, 40 bahagian setiap seratus resin (phr) telah didedahkan kepada pencuacaan semula jadi selama 3 dan 6 bulan. Sampel komposit telah dicirikan dengan spektroskopi transformasi Fourier inframerah, FTIR), mesin pengujianan universal, microskop imbasan elektron berosolusi pancaran medan, FESEM) dan kalorimetri imbasan perbezaan (DSC). Analisis FTIR menunjukkan puncak karbonil yang jelas bagi komposit selepas terdedah kepada pencuacaan yang menunjukkan pengoksidaan telah berlaku. Peratusan kehilangan berat komposit meningkat dengan tempoh pendedahan disebabkan penyerapan sinaran UV. Sifat lenturan komposit yang terdedah kepada pencuacaan lebih rendah berbanding komposit kawalan dan sifat ini juga berkurang dengan peningkatan tempoh pendedahan. Mikrograf FESEM menunjukkan komposit dengan tempoh pendedahan yang lebih panjang mengalami lebih kerosakan morfologi permukaan. Peratusan penghabluran didapati meningkat dengan peningkatan tempoh pendedahan.

Kata kunci: Degradasi; kenaf (KNF); pencuacaan semula jadi; penghabluran polietilena berketumpatan rendah linearl poli (vinil alkohol) (LLDPE/PVOH)

\section{INTRODUCTION}

The increasing environmental awareness has challenged researchers, engineer and manufacturers to practice environmental friendly goals in various aspects (Azwa et al. 2013, Pickering et al. 2016). Natural fibers such as kenaf (KNF), wood, jute, hemp and bagasse have become an ideal choice as biodegradable materials to blend with thermoplastics and utilized in different applications
(Balaji et al. 2014; Husseinsyah et al. 2016; Pang et al. 2015). KNF based polymer composites are being increasingly used in automotive parts such as car door panels, seat back board and door trim due to their light weight, low cost and environmental friendly (Kamal et al. 2014; Pai \& Jagtap 2015). However, KNF based polymer composites are vulnerable to outdoor environment factors; comprising Ultra-violet (UV) light, temperature, 
moisture and chemical agents (acids, bases, ozone, organic solvents) (Nechifor 2016; Sarifuddin et al.2014). In regard to this, it is essential to diversify researches on the degradability of KNF based polymer composites under various weathering conditions.

Weathering is a natural phenomenon, whereby the exposed materials undergo some degree of ageing during their lifetime and subsequently, causing deteriorations in terms of mechanical properties, chemical structure and physical changes (Azwa et al. 2013; Nechifor 2016). Many researches explored the effect of natural weathering on properties of natural fibers/thermoplastic composites. For instance, Badji et al. (2017) investigated the visual aspect, surface topography and mechanical properties of wood-polypropylene composites under natural weathering conditions. They noted that degradation by weathering has induced surface roughness, gloss loss and decrease in tensile properties of the composites, particularly at higher wood fraction. Nazrul Islam et al. (2013) observed that the mechanical properties of oil palm trunk lumber (OPTL) green composites decreased with an increasing natural weathering time.

Although there are ample studies on the degradation by natural weathering of natural fiber/plastic composites, nevertheless the emphasis on degradability of LLDPE/ $\mathrm{PVOH} / \mathrm{KNF}$ composites in natural weathering has yet to be investigated. Therefore, the novelty of this paper targets a comprehensive analysis on structural and weight loss changes, tensile properties, morphological changes as well as thermal properties of LLDPE/PVOH/KNF composites under different natural weathering exposure duration.

\section{EXPERIMENTAL DETAILS}

\section{MATERIALS AND PROCESSING}

The polymer matrices used in this study was a blend of LLDPE (60\% weight basis) and PVOH (40\% weight basis). LLDPE was supplied by PT. Lotte Chemical Titan Nusantara, Indonesia with $0.92 \mathrm{~g} / \mathrm{cm}^{3}$ (density) and $1 \mathrm{~g} / 10 \mathrm{~min}$ at $190^{\circ} \mathrm{C}$ (melt flow rate), respectively. PVOH was purchased from Sigma-Aldrich (M) Sdn. Bhd., Malaysia with 1.269 $\mathrm{g} / \mathrm{cm}^{3}$ (density) and 89,000 to $98,000 \mathrm{~g} / \mathrm{mol}$ (molecular weight), respectively. The filler used in this study was KNF with various loadings at $10 \mathrm{phr}, 20 \mathrm{phr}$ and $40 \mathrm{phr}$. KNF was obtained from National Kenaf and Tobacco Board (LKTN), Kelantan, Malaysia in long fiber form. KNF was grinded into the particle size of $<75 \mu \mathrm{m}$; and dried in oven at $80^{\circ} \mathrm{C}$ for $24 \mathrm{~h}$ prior to its usage. The processing of the composites was carried out using Thermo Haake internal mixer, (Model R600/610 from LMS Scientific Solution Sdn. Bhd., Malaysia) at temperature and rotor speed of $150^{\circ} \mathrm{C}$ and $50 \mathrm{rpm}$, respectively. Subsequently, the composites were pressed at $150^{\circ} \mathrm{C}$ using an electrically heated hydraulic press (GoTech Testing Machine, Model KT-7014 A from GoTech Testing Machine Inc., Taiwan) for $11 \mathrm{~min}$.

\section{NATURAL WEATHERING}

Natural weathering test conducted in this study was based on ASTM D1435. The dumbbell-shaped of LLDPE/PVOH/ KNF composites were mounted on an exposure rack at $45^{\circ}$ inclination angle and exposed to outdoor weathering in Universiti Sains Malaysia (USM), Penang, Malaysia (latitude $5^{\circ} 8^{\prime} \mathrm{N}$, longitude $100^{\circ} 29^{\prime} \mathrm{E}$ ) in the year 2015 . The meteorology data such as average temperature and rainfall were obtained from nearby meteorology station in Butterworth, Penang, Malaysia (latitude $5^{\circ} 21^{\prime} \mathrm{N}$, longitude $100^{\circ} 24^{\prime} \mathrm{E}$ ). Figure 1 depicts the monthly average temperature and rainfall during the natural weathering exposure (3 and 6 months) in the year of 2015. The dumbbell-shaped samples were mounted on an exposure rack facing to the south and at an inclination angle of $45^{\circ}$. After the exposure period, the samples were subjected to further mechanical and analytical tests.

\section{FOURIER TRANSFORM INFRARED SPECTROSCOPY (FTIR) ANALYSIS}

FTIR was used to determine the presence of functional groups present on composite surface before and after natural weathering exposure. The FTIR analysis was performed using FTIR-Perkin Elmer System 2000 Spectrometer (Perkin Elmer Sdn. Bhd., Malaysia). For each spectrum, the resolution and scanning range used were 4 $\mathrm{cm}^{-1}$ and $4000-550 \mathrm{~cm}^{-1}$, respectively.

\section{TENSILE PROPERTIES}

Tensile tests were completed using a Universal Testing Machine (LMS Scientific Solution Sdn. Bhd., Malaysia) in accordance with ASTM D638-Type IV. The tests were carried out on dumbbell-shaped samples (1 mm thick) at $25 \pm 3^{\circ} \mathrm{C}$, with a crosshead speed of $5 \mathrm{~mm} / \mathrm{min}$. The gauge length was kept constant at $50 \mathrm{~mm}$. For each KNF loading, five samples were tested to acquire average values for tensile strength, tensile modulus and elongation at break. The retention of the tensile properties was calculated as shown in the following equation:

$$
\text { Retention }(\%)=\frac{\text { Value after Natural Weathering }}{\text { Value before Natural Weathering }} \times 100 \%
$$

\section{SURFACE MORPHOLOGY}

A Zeiss Supra-35vp FESEM (Carl Zeiss NTS GmbH, Germany) was used to observe weathered samples surface. The samples were conductively coated with a thin layer of gold to prevent electrostatic charging, before mounted onto aluminum stage for scanning.

\section{WEIGHT LOSS}

The weight loss percentage of weathered samples was calculated via the following equation:

$$
\text { Weight Loss }(\%)=\frac{\mathrm{W}_{0}-\mathrm{W}_{1}}{\mathrm{~W}_{0}} \times 100
$$




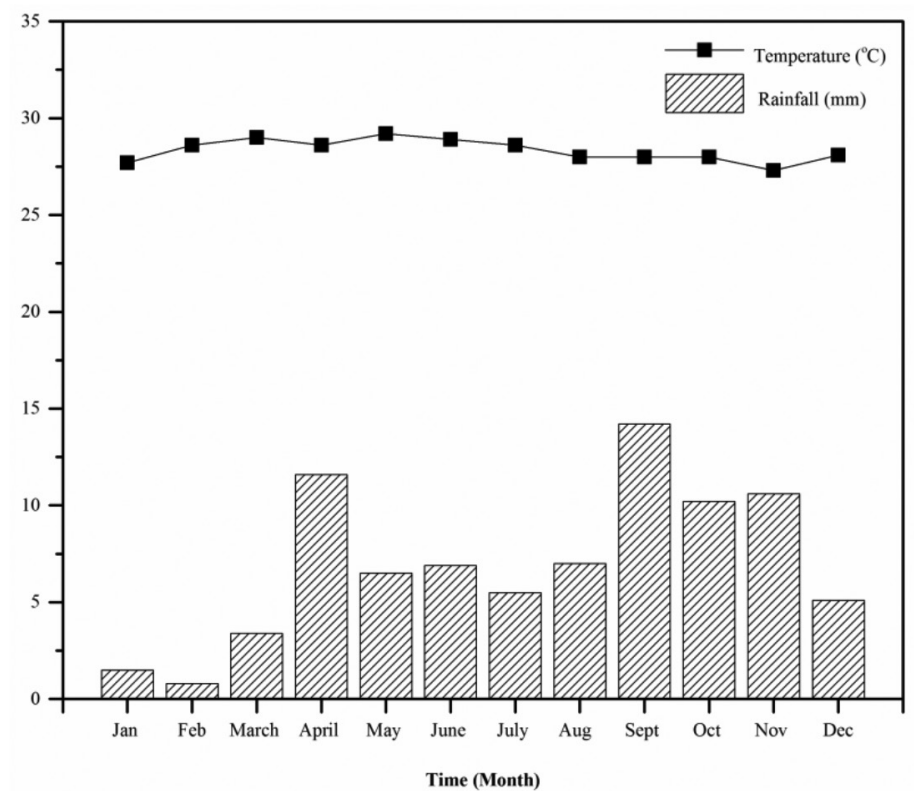

FIGURE 1 . The monthly average temperature and rainfall during the natural weathering exposure in the year of 2015

where and are the weights of sample before and after natural weathering exposure, respectively.

\section{DIFFERENTIAL SCANNING CALORIMETRY (DSC)}

Thermal analysis of weathered LLDPE/PVOH/KNF composites was carried out using Perkin-Elmer DSC 7 thermal analyser (Perkin Elmer Sdn. Bhd., Malaysia). The test was carried out under a nitrogen atmosphere which is in accordance with ASTM D3418. The sample (5 to $10 \mathrm{mg}$ ) was capsulated in an aluminium crucible and exposed to heating and cooling cycles. The heating and cooling rate maintained at a constant rate of $10^{\circ} \mathrm{C} / \mathrm{min}$, with a temperature range of 30 to $170^{\circ} \mathrm{C}$. The area under the endothermic curve was used to calculate the heat of fusion. As the heat of fusion is directly proportional to the amount of crystalline LLDPE in the sample, thus it decreases as KNF loading increases. The percentage of crystallinity can be calculated based on the following equation:

$$
\mathrm{X}_{\mathrm{c}} \text {, crystallinity }(\%)=\frac{\Delta \mathrm{H}_{\mathrm{f}}^{*}}{\mathrm{~W}_{\mathrm{f}} \times \Delta H_{\mathrm{f}}^{0}} \times 100
$$

where is the heat of fusion for fully crystalline LLDPE (290 J/g) (Ismail et al. 2009), is the experimental heat of fusion for composites and is the weight fraction of LLDPE in composites.

\section{RESULTS AND DISCUSSION}

\section{FOURIER TRANSFORM INFRARED (FTIR) ANALYSIS}

FTIR spectra of LLDPE/PVOH/40 phr KNF composites before, after 3 months and 6 months of natural weathering exposure are shown in (Figures 2(a)-2(c)). The spectrum of composites before weathering exposure (Figure 2(a)) contains the characteristic peaks at $3400-3200 \mathrm{~cm}^{-1}(\mathrm{OH}$ stretching), 2916-2848 $\mathrm{cm}^{-1}$ ( $\mathrm{CH}$ and $\mathrm{CH}_{2}$ stretching), 1720 $\mathrm{cm}^{-1}$ (C=O group), $1645 \mathrm{~cm}^{-1}$ (OH groups of adsorbed water), $1462 \mathrm{~cm}^{-1}$ ( $\mathrm{CH}_{2}$ bending), 1368-1324 $\mathrm{cm}^{-1}$ (CH and $\mathrm{C}-\mathrm{O}$ bending vibration), $1245 \mathrm{~cm}^{-1}$ (C-O stretching), 1144-1056 $\mathrm{cm}^{-1}$ (C-O-C stretching vibration), $990 \mathrm{~cm}^{-1}$ (C-C, C-OH, CH vibrations) and $898-719 \mathrm{~cm}^{-1}$ (CH and $\mathrm{CH}_{2}$ stretching vibration) (Onggo \& Pujiastuti 2010; Pang et al. 2016; Sarifuddin et al. 2014). Moreover, all peaks (1245, 1144-1056, 990, 898-719 $\left.\mathrm{cm}^{-1}\right)$ belong to cellulose, hemicelluloses or lignin of KNF (Harini \& Harsojo 2014; Pang et al.2017). As can be seen in Figure 2(b) and 2(c), the peak intensity of $\mathrm{C}=\mathrm{O}$ (carbonyl group) and $\mathrm{OH}$ (hydroxyl group) increased with increasing weathering duration due to the oxidation of composites surface (Badji et al. 2017) and KNF being exposed on the weathered composite surface (Sarifuddin et al. 2014). In addition, it is obvious that the characteristic peaks of cellulose, hemicelluloses or lignin of KNF decreased with prolonged weathering duration is probably attributed to KNF being detached from the exposed composite surfaces, as shown in the later surface morphology micrographs.

\section{WEIGHT LOSS}

Generally, materials that are exposed to degradation tend to experience mass changes which can be observed by comparing mass before and after degradation duration. Figure 3 presents the weight loss percentage of LLDPE/ $\mathrm{PVOH} / \mathrm{KNF}$ composites after 3 months and 6 months of natural weathering exposure. It shows that the percentage of weight loss increased with the increase in KNF loading and exposure time. This result indicates that photodegradation occurs during weathering and causes UV 


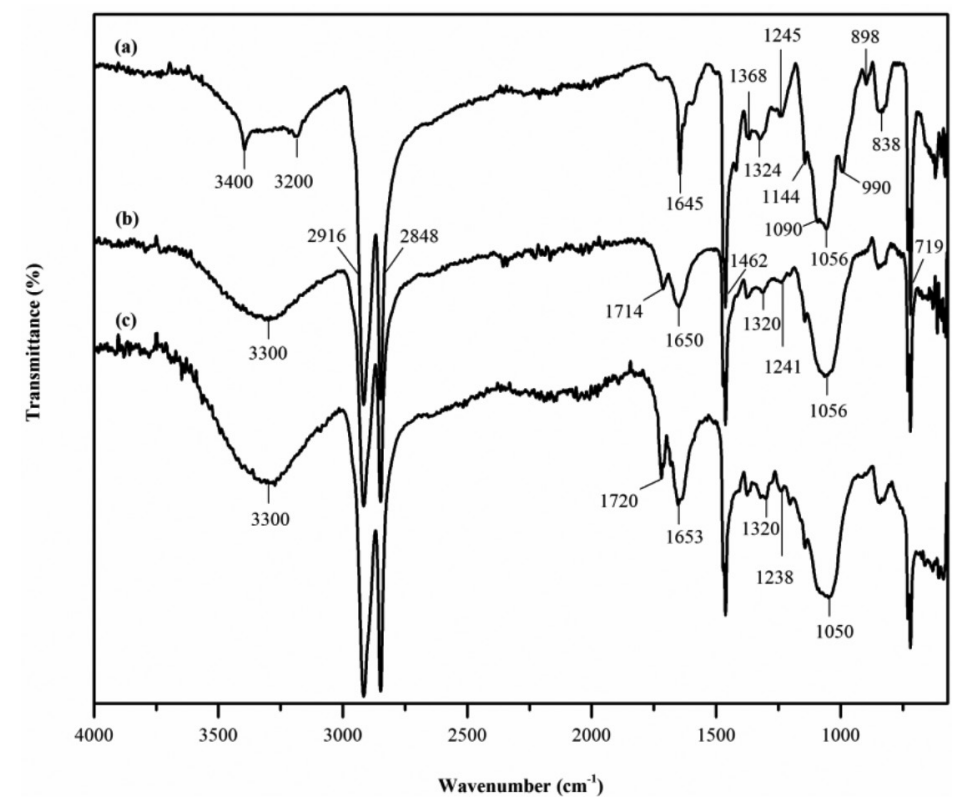

FIGURE 2. FTIR spectra of LLDPE/PVOH/40 phr KNF composites at (a) before, (b) after 3 months and (c) after 6 months natural weathering exposure, respectively

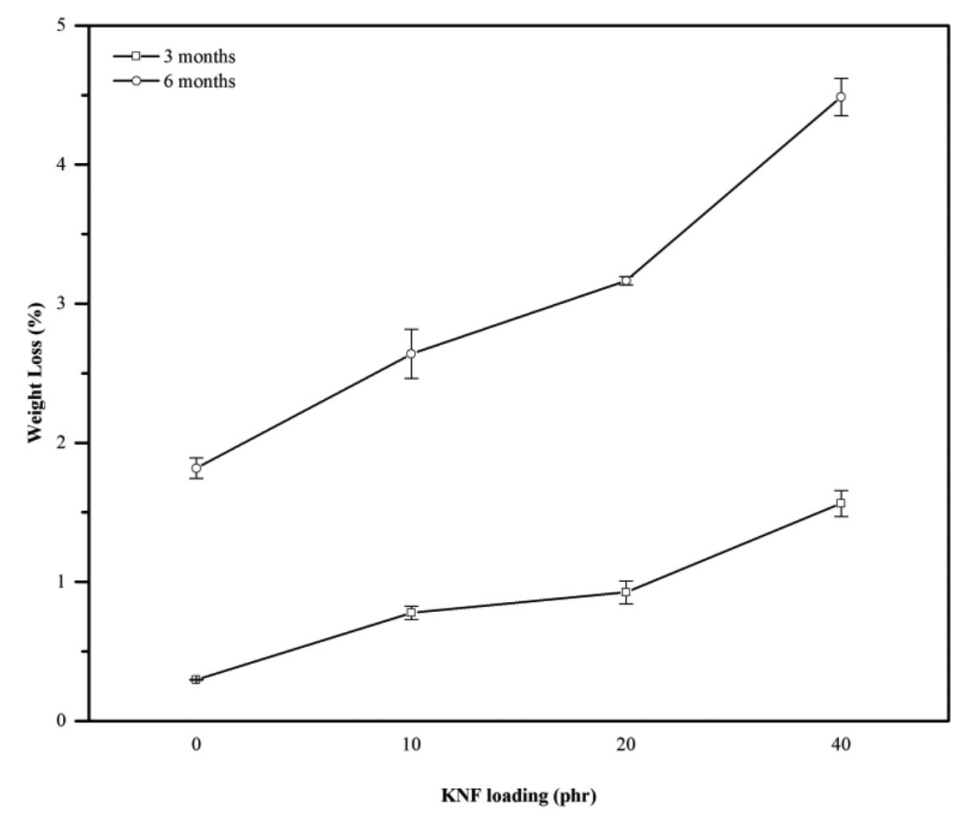

FIGURE 3. Weight loss of LLDPE/PVOH/KNF composites after 3 months and 6 months natural weathering exposure, respectively

radiation absorption by both LLDPE/PVOH matrices and KNF. The photo-degradation due to the absorption of ultraviolet radiation induces the occurrence of polymer chain scission as well as the leaching of fibers components from the exposed sample surfaces (Azwa et al. 2013; Nazrul Islam et al. 2013). Composites with $40 \mathrm{phr}$ KNF possess the highest weight loss percentage which can be attributed to the higher amount of KNF detached from composite surfaces. Meanwhile, the increase in percentage of weight loss with prolonged weathering exposure was expected. As discussed earlier, photo-degradation of polymers or fiber components is aided by UV radiation. Therefore, composites that are exposed to longer weathering condition tend to experience higher absorption of UV radiation, causing significant deterioration in the molecular weight.

\section{TENSILE PROPERTIES}

Tensile properties of LLDPE/PVOH/KNF composites before, after 3 months and 6 months of natural weathering exposure are depicted in Figures 4 to 6 , respectively. Figure 4 depicts that the tensile strength of LLDPE/ $\mathrm{PVOH} / \mathrm{KNF}$ composites decreased with an increase in weathering exposure duration. As can be seen in Figure 
4 , the retention of tensile strength decreased at longer weathering exposure duration. The reduction in tensile strength and its retention after weathering exposure are probably attributed to the degradation of LLDPE/PVOH matrices as well as KNF, resulting from the combined effects of ultra-violet (UV) radiation, oxygen, heat and water. The degradation of LLDPE/PVOH matrices is due to photo-oxidation that is promoted by the combination of UV radiation and oxygen. Fabiyi and McDonald (2014) and Sarifuddin et al. (2014) claimed that the exposure of polymers to UV radiation resulted in chain scission and/ or chain crosslinking due to oxidation of polymers. The absorption of UV radiation by LLDPE/PVOH matrices can probably induce chain scission reaction of the polymer main chain. Furthermore, the degradation of KNF is because of the absorption of UV radiation causing the breakdown of its components (cellulose, hemicelluloses and lignin) to form chromophoric functional groups such as carbonyls, carboxylic acids, quinones and hydroperoxy radicals. This leads to the deterioration in molecular weight and mechanical properties of the composites. The obtained results are in agreement with the earlier report by Nazrul Islam et al. (2013), Silva et al. (2017) and Zaaba et al. (2015).

Elongation at break is one of the most crucial tensile properties that are used when studying polymer degradation, as it can give an early indication of mechanical failure (Spinace \& De Paoli 2015). Similar trend has been observed for the elongation at break (Figure 5) of LLDPE/PVOH/KNF composites before, after 3 months and 6 months of natural weathering exposure, respectively. The elongation at break was found to have decreased from $7.5 \%$ to $5.9 \%$ after 3 months of exposure and continued to decline to $5.4 \%$ after 6 months of exposure. In addition, the retention of elongation at break for composites after 6 months of exposure is lower than that of composites after 3 months of exposure (Figure 5). This may be due to the extensive chain scission of LLDPE/PVOH matrices and detachment of KNF after a prolonged weathering period. The flexibility of the composites is educed as the polymer chain length decreases by photo-oxidation. Furthermore, the surface cracks on composites expose its inner layer to the degradation factors at prolonged weathering duration, resulting in the matrix loss and KNF detachment. Thus, the deformability of the composites declined after weathering. This is similar to the earlier reports by Sarifuddin et al. (2014) and Zaaba et al. (2015).

Figure 6 demonstrates the tensile modulus of LLDPE/ $\mathrm{PVOH} / \mathrm{KNF}$ composites before, after 3 months and 6 months of natural weathering exposure, respectively. Tensile modulus displays a similar trend with tensile strength and elongation at break. The introduction of KNF has increased the stiffness of LLDPE/PVOH matrices, and this stiffening effect increased with the loading of KNF (Pang et al. 2016). However, after being exposed to natural weathering, it is visible that the tensile modulus showed a decline trend and it continued to decline after a longer exposure period (6 months). The retention of tensile modulus was found to be lower in composites after 3 months as compared to composites after 6 months of weathering exposure (Figure 6). This is probably due to the moisture absorption and photo-oxidation of polymer composites, thereby forming cracks on the sample's surface. Subsequently, the interfacial adhesion between LLDPE/PVOH matrices and KNF was reduced and resulted in lower composites stiffness. Araoye et al. (2016) and Hung et al. (2012) have reported similar tensile modulus reduction under the effect of natural weathering.

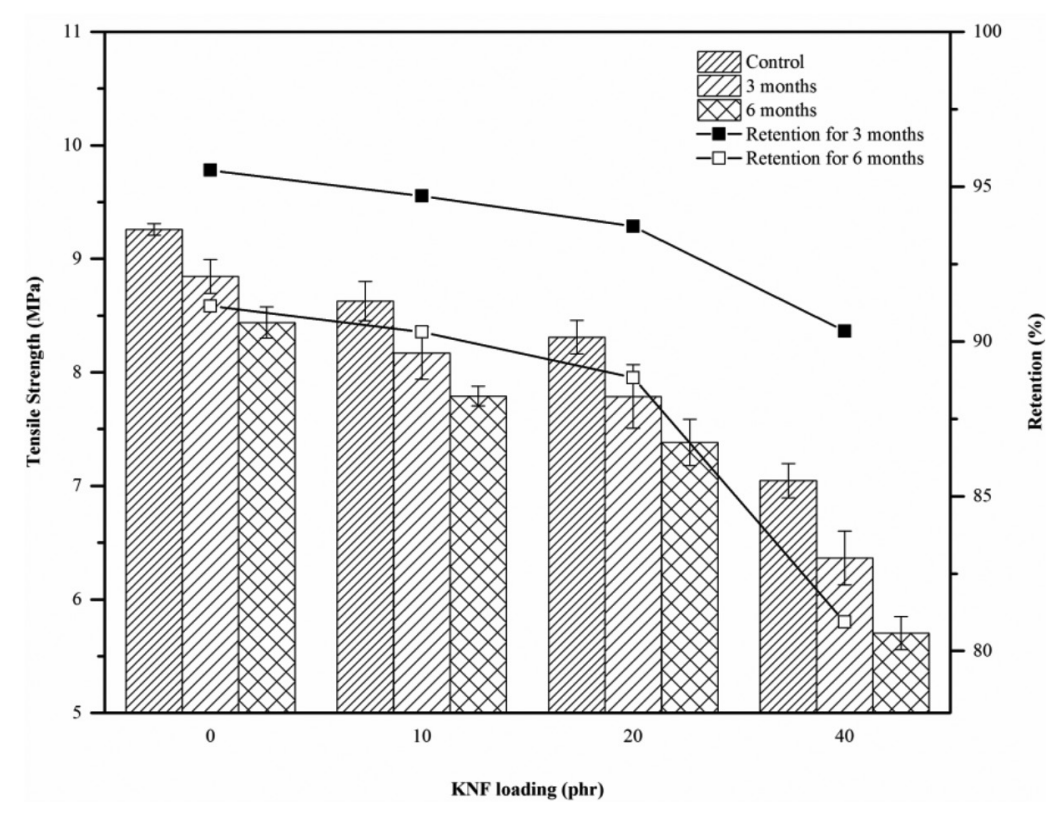

FIGURE 4. Tensile strength of LLDPE/PVOH/KNF composites before, after 3 months and 6 months natural weathering exposure, respectively 


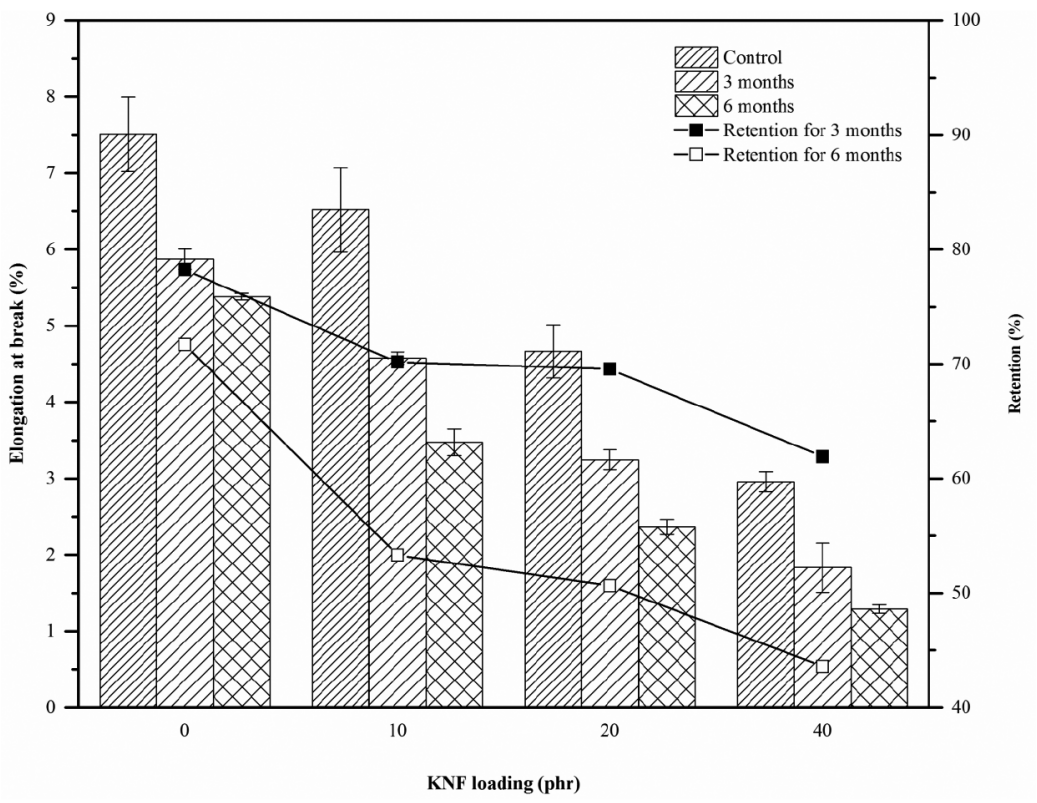

FIGURE 5. Elongation at break of LLDPE/PVOH/KNF composites before, after 3 months and 6 months natural weathering exposure, respectively

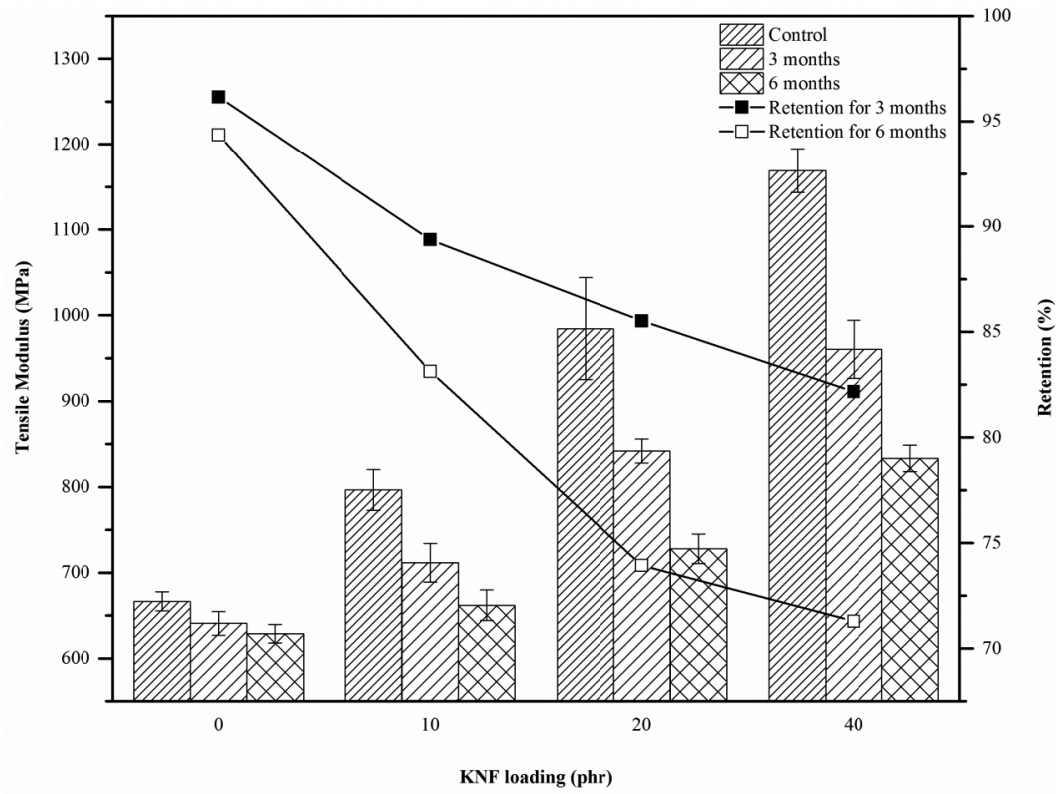

FIGURE 6. Tensile modulus of LLDPE/PVOH/KNF composites before, after 3 months and 6 months natural weathering exposure, respectively

\section{SURFACE MORPHOLOGY}

Figure 7 shows the surface morphology comparison of LLDPE/PVOH/KNF composites at various KNF loadings, before and after 3 months and 6 months of natural weathering exposure, respectively. By comparing Figures 7(a) and 7(b), there are many micro-cracks on LLDPE/ $\mathrm{PVOH}$ matrices surface after 3 months of weathering exposure. These micro-cracks were observed to have propagated after 6 months of weathering exposure, as shown in Figure 7(c). The formations of micro-cracks on LLDPE/PVOH matrices were due to the cyclic expansion and contraction of the samples as a result of inconsistent climate changes. According to Homkhiew et al. (2014) and Sarifuddin et al. (2014), the formation of surface cracks after weathering were related to the wetting and drying cycle's resulting from daily fluctuation in temperature and humidity. Referring to Figure 7(e), 7(f), 7(h) and 7(i), it is visible that composites with $40 \mathrm{phr} \mathrm{KNF}$ (Figure 7(h) \& 7(i)) exhibited a highly damage surface with deeper cracks as compared to composites with 10 phr KNF (Figure 7(e) and 7(f)) after weathering. This shows that the presence of $\mathrm{KNF}$ has increased the degradation rate of LLDPE/PVOH/KNF 
composites. A similar result was reported by Zaaba et al. (2015), who found that higher peanut shell powder loading in recycled polypropylene had the tendency to accelerate the degradation of the composites.

As the weathering duration increased, the severity of surface damage increased for LLDPE/PVOH/KNF composites at all KNF loadings. It is clearly noted that after 3 months of weathering exposure (Figure 7(e) and 7(h)), the surface cracks propagated further and KNF protruded from the composites surface. Meanwhile, the composites surface was remarkably changed after 6 months of weathering exposure, particularly for composites with 40 phr KNF (Figure 7(i)). The exposed composites surface was seriously damaged and it became rougher with remarkable matrix loss. In addition, there are many cavities were formed, resulting from KNF detachment from the surface of composites. These findings are probably due to the photo-oxidation by UV radiation of the composites, causing weak adhesion between LLDPE/PVOH matrices and KNF. Chen et al. (2016) also reported that the boundary between wood flour and high density polyethylene (HDPE) were disconnected due to the photo-oxidation by UV radiation. Subsequently, the ability to transfer stress between fiber-matrix became inefficient and led to lower tensile properties. This was in line with the tensile properties results.

\section{DIFFERENTIAL SCANNING CALORIMETRY (DSC)}

DSC melting and cooling thermograms of LLDPE/PVOH/40 phr KNF composites before and after natural weathering exposure are presented in Figures 8 and 9, respectively. From Figure 8, the endothermic peaks (assigned to melting temperature, $\mathrm{T}_{\mathrm{m}}$ ) showed no significant change for composites before and after weathering. This showed that there is an absence of new crystalline phase formed during degradation of LLDPE/PVOH/KNF composites. Nevertheless, the exothermic peaks in Figure 9 were found shifted to the right, signifying that crystalline temperature $\left(\mathrm{T}_{c}\right)$ has increased slightly after natural weathering. From these thermograms, the thermal parameters were extracted and used to calculate percentage of crystallinity based on (3). The changes in matrix crystallinity can be used as an indicator to evaluate degradation (Hung et al. 2012; Sam et al. 2013).

The DSC parameters are tabulated as in Table 1. The crystallinity of the composites was found to have decreased with increasing KNF loading as presented in Table 1, indicating that the addition of KNF could hinder the crystallization of LLDPE during cooling. Sam et al. (2015) reported a similar observation in regard to the crystallinity reduction whereby it is due to the increasing filler loading. Nevertheless, the percentage of crystallinity increased with increasing weathering exposure duration. The increase in $T_{c}$ and crystallinity can probably be attributed to the degradation of amorphous region in LLDPE/PVOH/KNF composites. During weathering, the absorption of UV radiation by composites initiated the photo-oxidation process, thus leading to chain scission in LLDPE/PVOH matrices. It is believed that the shorter chains have sufficient chain mobility to recrystallize (Fabiyi \&
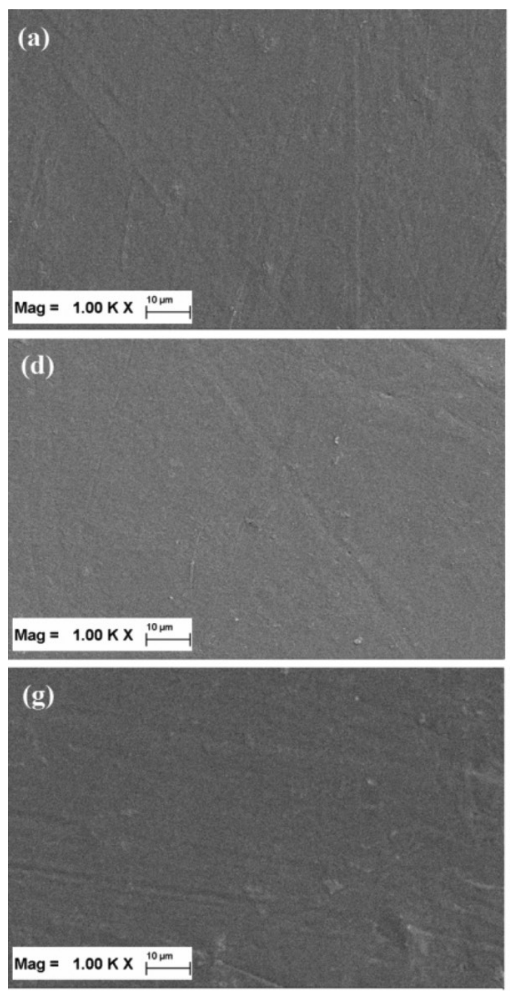
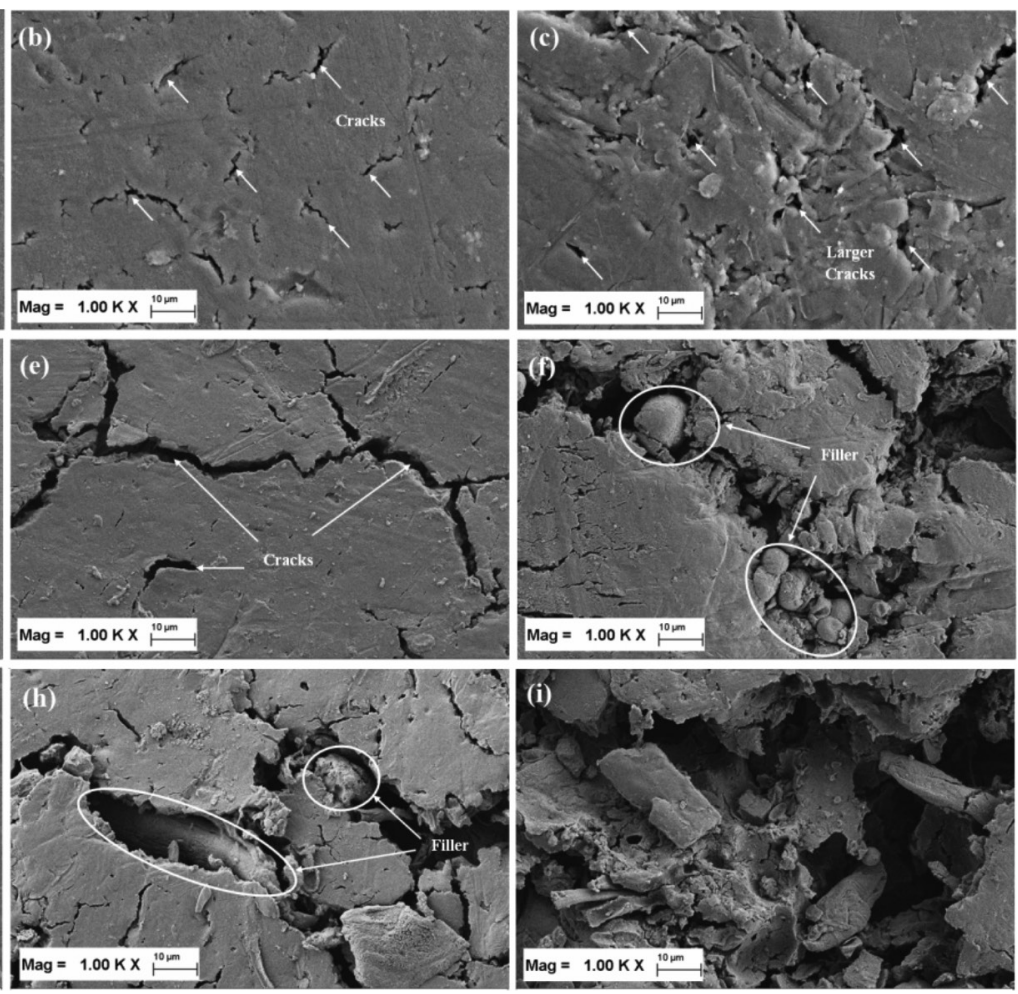

FIGURE 7. FESEM micrographs of LLDPE/PVOH/KNF composites filled with (a-c) 0 phr KNF, (d-f) 10 phr KNF, (g-i) 40 phr KNF before and after 3 months and 6 months weathering exposure, respectively 


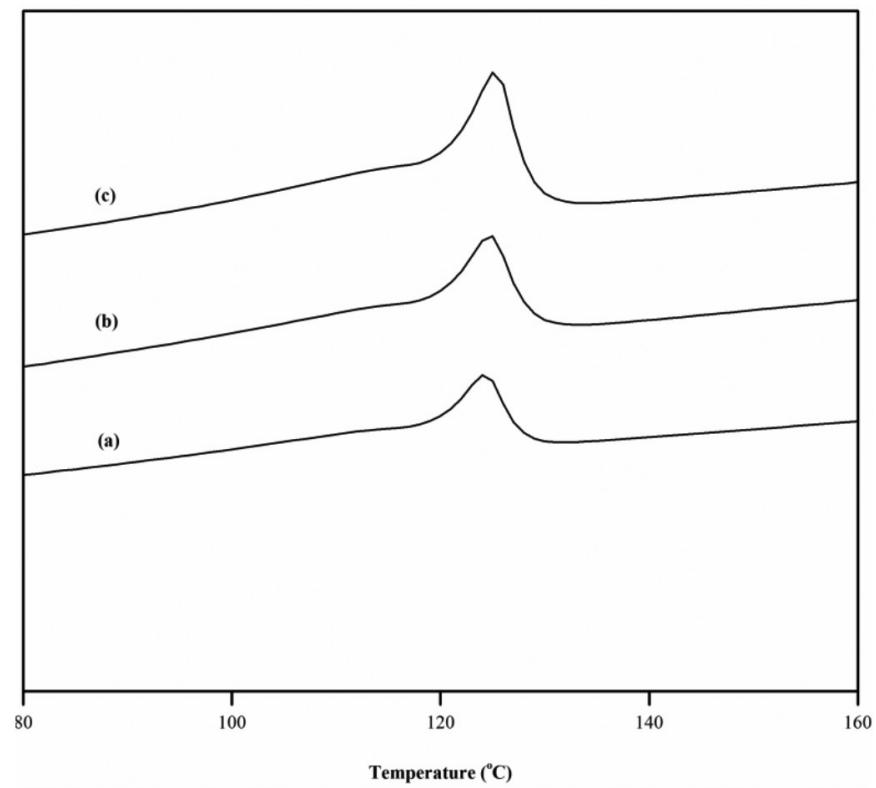

FIGURE 8. DSC melting themogram of LLDPE/PVOH/40 phr KNF composites at (a) before,

(b) after 3 months and (c) after 6 months natural weathering exposure, respectively

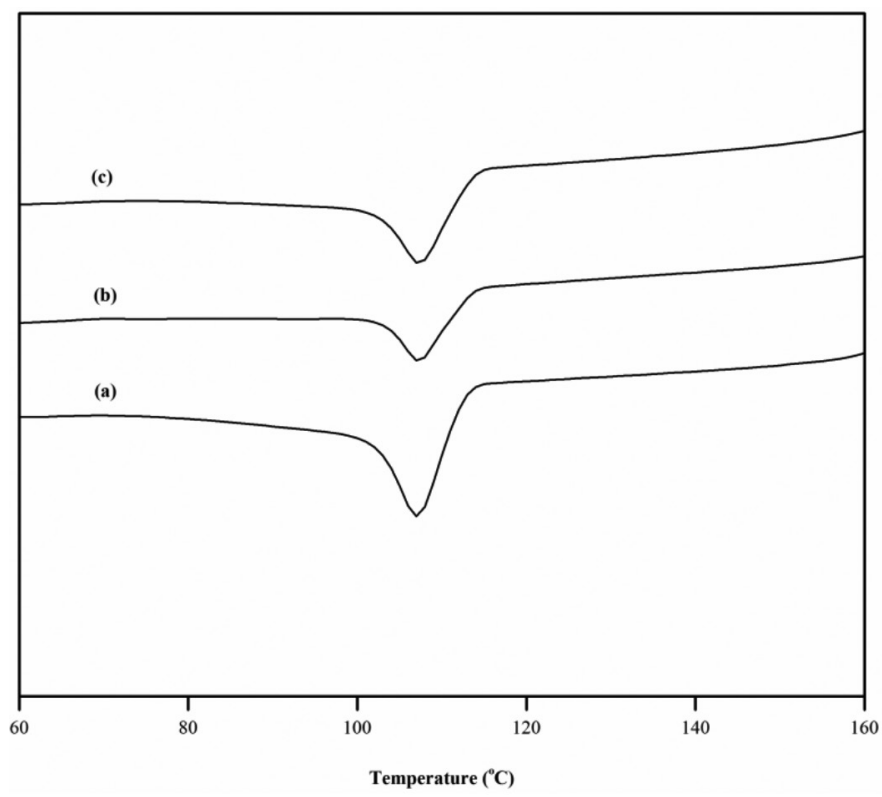

FIGURE 9. DSC cooling themogram of LLDPE/PVOH/40 phr KNF composites at (a) before,

(b) after 3 months and (c) after 6 months natural weathering exposure, respectively

TABLE 1. DSC parameters of LLDPE/PVOH/KNF composites before, after 3 months and 6 months natural weathering exposure

\begin{tabular}{lcccccc}
\hline \multirow{2}{*}{ Sample } & \multicolumn{4}{c}{$\mathrm{H}_{\mathrm{f}}\left(\mathrm{J} \mathrm{g}^{-1}\right)$} & \multicolumn{2}{c}{$\mathrm{X}_{\mathrm{c}}(\%)$} \\
\cline { 2 - 7 } & Before & $\begin{array}{c}\text { After 3 } \\
\text { months }\end{array}$ & $\begin{array}{l}\text { After 6 } \\
\text { months }\end{array}$ & Before & $\begin{array}{c}\text { After 3 } \\
\text { months }\end{array}$ & $\begin{array}{c}\text { After 6 } \\
\text { months }\end{array}$ \\
\hline LLDPE/PVOH & 29.1 & 38.2 & 61.8 & 16.7 & 22.0 & 35.5 \\
LLDPE/PVOH/10 phr KNF & 25.3 & 34.2 & 39.5 & 16.2 & 21.8 & 25.2 \\
LLDPE/PVOH/20 phr KNF & 18.9 & 31.5 & 33.2 & 13.0 & 21.7 & 22.9 \\
LLDPE/PVOH/40 phr KNF & 15.3 & 17.2 & 22.8 & 12.3 & 13.8 & 18.3 \\
\hline
\end{tabular}


McDonald 2014; Homkhiew et al. 2014; Spinace \& De Paoli 2015). Hung et al. (2012) also reported that the increase in crystallinity of weathered samples was mainly attributed to the chain scission in amorphous region of polymer, with crystalline region remained unaffected.

\section{CONCLUSION}

Surface chemical analysis by FTIR indicated that the surface oxidation (carbonyl groups content) of LLDPE/PVOH/KNF composites increased during natural weathering exposure. Besides that, the weight loss of composites increased with increasing KNF loading and weathering exposure duration. Furthermore, the tensile properties deteriorated after weathering and gradually decreased with increasing weathering exposure duration. FESEM analysis on exposed surfaces proved that the increase in weathering exposure duration has led to the increase of the degradability of composites. The increase in crystallinity of LLDPE after natural weathering confirmed the occurrence of the degradation of composites. Therefore, this study concludes that higher degradability was observed in LLDPE/PVOH/ KNF composites with increasing KNF loading and natural weathering exposure duration.

\section{ACKNOWLEDGEMENTS}

The authors would like to extend their gratitude to National Kenaf and Tobacco Board (LKTN), Kelantan, Malaysia, for the KNF fiber supply and RUC research grant (1001/ PKT/8640014) from Universiti Sains Malaysia for the financial supports.

\section{REFERENCES}

Araoye, B.O., Kasim, A., Abdulwahab, M. \& Shehu, U. 2016. Properties evaluation of natural weathered polyester/ nano-locust bean pods ash (LBPA) composite. Industrial Engineering Letters 6: 1-11.

ASTM D3418. 2012. Standard Test Method for Transition Temperatures and Enthalpies of Fusion and Crystallization of Polymers by Differential Scanning Calorimetry. West Conshohocken: ASTM International.

ASTM D638.2010. Standard Test Methodfor Tensile Properties of Plastics. West Conshohocken: ASTM International.

ASTM D1435. 1999. Standard Practice for Outdoor Weathering of Plastics. West Conshohocken: ASTM International.

Azwa,Z.N., Yousif, B.F., Manalo, A.C. \& Karunasena, W. 2013. A review on the degradability of polymeric composites based on natural fibers. Materials and Design 47: 424-442.

Badji, C., Soccalingame, L., Garay, H., Bergeret, A. \& Benezet, J.C. 2017. Influence of weathering on visual and surface aspect of wood plastic composites: Correlation approach with mechanical properties and microstructure. Polymer Degradation and Stability 137: 162-172.

Balaji, A. Karthikeyan, B . \& Sundar Raj, C. 2014. Bagasse fiberthe future of biocomposite material: A review. International Journal of ChemTech Research 7: 223-233.

Chen, Y., Stark, N.M., Tshabalala, M.A., Gao, J.M. \& Fan, Y.M. 2016. Weathering characteristics of wood plastic composites reinforced with extracted or delignified wood flour. Materials 9: 610-621.

Fabiyi, J.S. \& McDonald, A.G. 2014. Degradation of polypropylene in naturally and artificially weathered plastic matrix composites. Maderas Ciencia Technology 16(3): 275-290.

Harini, S.\& Harsojo. 2014. Effect of combined treatment methods on the crystallinity and surface morphology of kenaf bast fibers. Cellulose Chemistry and Technology 48: 33-43.

Homkhiew, C., Ratanawilai, T. \& Thongruang, W. 2014. Effects of natural weathering on the properties of recycled polypropylene composites reinforced with rubberwood flour. Industrial Crops and Products 56: 52-59.

Hung, K.C., Chen, Y.L. \& Wu, J.H. 2012. Natural weathering properties of acetylated bamboo plastic composites. Polymer Degradation and Stability 97: 1680-1685.

Husseinsyah, S., Chun, K.S., Yeng, C.M. \& Ismail, A. 2016. Tensile, thermal and water absorption properties of corn stalk filled low density polyethylene composites: Effect of coconut oil coupling agent. Sains Malaysiana 45(11): 1733-1739.

Ismail, H., Ahmad, Z., Nordin, R. \& Rashid, A. 2009. Processibility and miscibility studies of uncompatibilized linear low density polyethylene/poly (vinyl alcohol) blends . Polymer-Plastics Technology and Engineering 48: 11911197.

Kamal, I., Thirmizir, M.Z., Beyer, G., Saad, M.J., Abdul Rashid, N.A. \& Abdul Kadir, Y. 2014. Kenaf for biocomposite: An overview. Journal of Science and Technology 6: 41-66.

Nazrul Islam, M., Dungani, R., Abdul Khalil, H.P.S., Siti Alwani, M. \& Wan Nadirah, W.O. 2013. Natural weathering studies of oil palm trunk lumber (OPTL) green polymer composites enhanced with oil palm shell (OPS) nanoparticles. SpringerPlus 2: 592-603.

Nechifor, M. 2016. Factors influencing the photochemical behavior of multicomponent polymeric materials. Photochemical Behavior of Multicomponent Polymeric-based Materials, Advanced Structure Materials 26: 21-65.

Onggo, H. \& Pujiastuti, S. 2010. Effect of weathering on functional group and mechanical properties of polypropylenekenaf composites. Indonesian Journal of Materials Science 11: 123-128.

Pai, A.R. \& Japtap, R.N. 2015. Surface morphology \& mechanical properties of some unique natural fiber reinforced polymer composites - A review. Journal of Materials and Environmental Science 6: 902-917.

Pang, A.L., Ismail, H., \& Abu Bakar, A. 2017. Degradation of linear low-density polyethylene/poly(vinyl alcohol)/kenaf composites. Iranian Polymer Journal DOI: 10.1007/s13726017-0555-8.

Pang, A.L., Ismail, H. \& Abu Bakar, A. 2016. Tensile properties, water resistance, and thermal properties of linear low-density polyethylene/polyvinyl alcohol/kenaf composites: Effect of 3-(trimethoxysilyl) propyl methacrylate (TMS) as a silane coupling agent. Bioresources 11(3): 5889-5904.

Pang, A.L., Ismail, H. \& Abu Bakar, A. 2015. Effects of kenaf loading on processability and properties of linear lowdensity polyethylene/poly (vinyl alcohol)/kenaf composites. Bioresources 10(4): 7302-7314.

Pickering, K.L., Aruan, M.G. \& Le, T.M. 2016. A review of recent developments in natural fiber composites and their mechanical performance. Composites: Part A 83: 98-112.

Sam, S.T., Hani, N. \& Ismail, H. 2015. The effect of epoxidized natural rubber (ENR 50) as a compatibilizer on spear grass 
filled low density polyethylene/soya spent powder. Sains Malaysiana 44(6): 787-792.

Sam, S.T., Ismail, H. \& Abdul Khalil, H.P.S. 2013. Degradation of epoxidized natural rubber compatibilized linear low density polyethylene/soya powder blends: The effect of natural weathering. Journal of Polymer Engineering 33(7): 579-588.

Sarifuddin, N., Ismail, H. \& Ahmad, Z. 2014. Incorporation of kenaf core fibers into low density polyethylene/thermoplastic sago starch blends exposed to natural weathering. Molecular Crystal and Liquid Crystal 603: 180-193.

Silva, C.B., Martins, A.B., \& Catto, A.L. 2017. Effect of natural ageing on the properties of recycled polypropylene/ethylene vinyl acetate/wood flour composites. Revista Materia 22(2): 11835-11851.

Spinace, M.A.S. \& De Paoli, M.A. 2015. Biocomposite of a multilayer film scrap and curaua fibers: Preparation and environmental degradation. Journal of Thermoplastic Composite Materials 2015: 1-16.

Zaaba, N.F., Ismail, H. \& Mariatti, J. 2015. A study of the degradation of compatibilized and uncompatilized peanut shell powder/recycled polypropylene composites due to natural weathering. Journal of Vinyl and Additive Technology DOI: $10.1002 / \mathrm{vnl} .21504$

Pang Ai Ling \& Azhar Abu Bakar

School of Materials and Mineral Resources Engineering

Universiti Sains Malaysia (USM)

Engineering Campus

14300 Nibong Tebal, Pulau Pinang

Malaysia
Hanafi Ismail*

School of Materials and Mineral Resources Engineering

Cluster of Polymer Composites (CPC)

Science and Engineering Research Centre (SERC)

Universiti Sains Malaysia (USM)

Engineering Campus

14300 Nibong Tebal, Pulau Pinang

Malaysia

*Corresponding author; email: ihanafi@usm.my

Received: 22 June 2017

Accepted: 5 October 2017 